\title{
Corruption and the Challenges of Good Governance in the Nigerian Public Sector
}

Fatile, Jacob Olufemi

Abstract

The role of the public service in achieving good governance cannot be underestimated. This can be gleaned from the central role it plays in the formulation and implementation of policies designed for the development of the society. In Nigeria, the role of public service has come under severe criticisms within the context of the gap that exists between its anticipated role and its actual output in guiding the society along the course leading to the desired goal as a result of corruption. This article observes that the fact that Nigeria is still grappling with the problems of bad governance goes to show the level of non-accountability and ever present manifestation of crude corruption that is open, naked, undisguised and yet legally untameable because of the system. The article also reveals that many of the anti-corruption efforts are part of the liberal reforms that are based on the assumption that corruption is an individual act or personal misuse of public office for private gain. It points out that as laudable as the intentions of government in putting in place institutions and laws meant to curb corruption, the enforcement of these laws has left much to be desired. In fact, the various reform efforts of the Nigerian government are of limited value because they fail to take into account much of the dynamics that support corruption in the country. Thus, people now regard the law as paper tigers, meant only to the enforced when breached by low-level public officers. While successive administrations have taken partially successful steps to control corruption, these efforts have not fundamentally undermined the supporting environment for corruption in the country. The article therefore recommends the need for greater transparency in the management of public funds by the public office holders as well as the need for political will and commitment from governments at Federal, State and Local, including bureaucracies at various levels of governance in the country. The article concludes that there is a need to consciously transform social values as well as state institutions that work as enabling environments for corruption. The leadership also has enormous responsibility in controlling corruption and restoring the hope to the citizenry through good governance. Unless good governance is in place with accountability carefully observed, sustainable development cannot be realized.

Keywords: Corruption, Good Governance, Service Delivery, Accountability, Nigeria. 


\section{Introduction}

In every society and community, there are certain behaviours, which are very much detested in the course of interpersonal relationships, and group behaviour. The behaviours include cheating, lying, etc. These behaviours which have moral, ethical, legal and religious implications are detested because they are inimical to proper and decent standards. The pattern of that encapsulates all this detested attitude is corruption (Omoluabi, 2007:3).

Corruption is a household name in every society nowadays and the negative impact it has on the socio-economic and political setting of a country can hardly be over emphasized. There has been a global cry and coordinated efforts to tackle this social evil through the creation and implementation of anti-graft laws and policies across nations. Some nations have been successful in their quest to reduce the level of corruption while others are still lagging behind. In this light, Nigeria seems to be an example of a state that failed in combating corruption. From the common man in the street to the highest political figure, corruption is recurrent in almost every transaction in the Nigerian society.

Within the last one decade, the issue of corruption and good governance has taken the centre stage in development discourse worldwide. Corruption is shaking the foundation of the nation as there is no sector that is not affected by this monster. The challenges of corruption remain a major devastating issue facing Nigeria since the colonial period, although, this phenomena has become a cankerworm that has eaten deep into the fabrics of our system (Muhammed, 2013:120).

Over the years, public sector in Nigeria has been characterized largely by ineffectiveness and inefficiency. The situation is not different in other African countries. High-level corruption has been identified as being responsible for Nigeria's underdevelopment and growing crimes rates. It is instructive to note that the Nigerian government and citizens have not totally committed themselves to introducing and implementing measures that can prevent or drastically reduce the extent and consequence of corruption in the country. That is not to say that laws, institutions and programmes for controlling corruption have not been introduced by successive governments. On the contrary, every Nigerian government since 1975 introduced elaborate laws and programmes, only for officials to turn such programmes into fertile opportunity for corrupt practices and enrichment. Consequently, there has been a geometrical growth in the rate of corruption in the country (Etannibi, 2002:2).

Etannibi (2002:9) also claimed that corruption is the source of many socioeconomic and political problems that have militated against the attainment of economic development, equity, social justice, political integration and stability as well as democracy in Nigeria. The employment, promotions, postings and deployment processes in the federal service are riddled with corruption, and it was estimated that Nigeria had lost to corruption as much as $\$ 400$ billion between 1966 and 1999 . Yet corruption in Nigeria preceded 1966 and has continued ever since beyond 2007 with 
greater ferocity and intensity (Olokor, 2013:2). Since the return of the country to civil rule on May 29, 1999, the Nigerian government has taken a number of measures to address the problems of corruption and bad governance in the country. Despite the successes attained by these measures, the situation remains unacceptable as corruption continues to permeate and pervade every facet of national life in Nigeria.

In this research article, the data for the study were basically selected from secondary materials such as textbooks, internet materials, newspapers, magazines, and journals articles, etc, through a systematic qualitative content analysis.

In discussing issues in this study, the article is divided into eight sections. The first section dealt with the introduction, the second focused on the conceptual exploration where corruption, governance and good governance were conceptualized while the third aspect treated the theoretical framework. In the fourth section, attempt was made to look at the historical development of corruption in Nigeria. The nature and causes of corruption is the focus of the fifth section. The sixth section takes a cursory look at the dilemma of corruption and good governance in Nigeria. In the seventh section, attempt was made to proffer remedial actions for the study, while the last section presented the concluding remarks.

\section{Comuption and Govemance: Conceptual Analysis}

Corruption is a universal phenomenon that cuts across nations, cultures, races, and classes of people in both developed and developing countries (Aderonmu, 2011:81). It is a multi-dimensional concept that has moral, ethical, religious and legal connotations (Omoluabi, 2007:9). Corruption is a multifaceted phenomenon that has multiple causes and effects. Scholars, policy makers and opinion leaders tend to be confused in the process of analysis due to complexity of the phenomenon as it takes on various forms. Defining activities as "corruption" is highly subjective and, as Levi and Nelken (1996:32) point out, 'corrupt' acts in some countries are seen as normal elsewhere. This made it possible for scholars to define corruption in different ways. In fact, it is easy to talk about corruption, but like other complex phenomena, it is difficult to define corruption in concrete terms. It is not surprising therefore that there is often no consensus as to what exactly constitutes this concept. There is always a danger as well that several people may engage in a discussion about corruption while each is talking about a different thing completely (Obayelu, 2007:19). According to Ikotun (2004:24) the term corruption comes from Latin word 'rumpere', (to break), implying that something is broken. This something might be moral or social code of conduct, more often, an administrative rule. Onuoha (2005:45) describes it as an illegal act, which involves inducement and/or undue influence of people either in the public setting or the private sphere to act contrary to the extant rules and regulations which normally guide a particular process. 
These definitions bring to light the extent to which corrupt practices are indulged and perpetrated. Corruption viewed from different perspectives by scholars, share some common concern. There is a general agreement among scholars that corruption is the abuse of entrusted power for private gain. It hurts everyone whose life, livelihood or happiness depends on the integrity of people in a position of authority. It is a serious societal problem about which something has to be done to reduce its occurrence and prevalence (Fatile \& Adejuwon, 2012:159).

Governance on the other hand has been defined as the use of political authority and exercise of control over society and the management of its resources for social and economic development. It encompasses the nature of functioning of a state's institutional and structural arrangements, decision making processes, policy formulation, implementation capacity, information flows, effectiveness of leadership and the nature of the relationship between rulers and the ruled (Doig, 1995:154-155). Governance can also be described as the use of authority and the exercise of control over society and the management of its resources for social and economic development. It is the manner in which power is exercised by governments in the distribution of a country's social and economic resources. The nature and manner of distribution is what makes governance good or bad one. Thus, according to Ogundiya (2010:238) when resources must be distributed to promote inequality or to achieve personal or group ambitions, the essence of governance which coincides with the essence of politics and essence of the state is defeated. Therefore, resources must be distributed responsibly, equitably and fairly for the realization of the essence of the state.

As noted by Okeke (2010:5), governance is said to have evolved from the need to organize society towards the achievement of a common goal. An opinion worth considering is that society derives its roots from the solitary man who later got transformed into a family person to fulfil the need for socialization. Within this union, he enjoyed the love, care and company of family members and recognised their inherent and inalienable rights in order to preserve the love, harmony and cohesion within the family. Society later grew out of the family in response to the need to fulfil other higher needs and the collective aspirations of the people, such as security, economic well-being and survival, through negotiations and the formation of social contract between the governors and the governed. Governance, therefore, concerns not just the integrity, efficiency and economy of government but also its effectiveness in terms of the ends to which government organization and activity are directed.

Good governance, therefore, refers to government that fulfils the terms of the social contract with the people. Good governance is a fundamental right in a democracy and it implies transparency and accountability. Good governance entails an administration that is sensitive and responsive to the needs of the people and is effective in coping with emerging challenges in society by framing and implementing appropriate laws and measures. It includes strict rules of accountability. Good governance largely depends on the extent to which the general citizenry perceives a government to be legitimate, i.e., committed to improving the general public welfare - deliver public services and 
equitable in its conduct - favouring no special interests or groups. It is among other things, participatory, transparent and accountable. It is also effective, equitable and promotes the rule of law. Good governance ensures that political, social and economic priorities are based on broad consensus in society and that the voices of the poorest and the most vulnerable are heard in decision-making over the allocation of development resources (Richardson, 2008).

Good governance however remains elusive with no limitation of scope that commands universal acceptance. The true test of good governance is the degree to which it delivers on the promise of human, civil, cultural, economic, political and social rights. It ensures that corruption is minimized, the views of minorities are taken into account and that the voices of the most vulnerable in society are heard in decisionmaking. It is also responsive to the present and future needs of society and the nation at large. Governance is good when it is able to achieve the desired end of the state defined in terms of justice, equity, protection of life and property, enhanced citizens' participation, preservation of rule of law and improved living standard of the populace (Ogundiya, 2010). There is no doubt that in Nigeria since the return to democratic rule in 1999, good governance has been elusive which many scholars believes is largely attributable to large scale level of corruption in different facets of the society and most especially the public sector.

\section{Theoretical Exploration}

At this juncture, our attention is directed to the review of some relevant theories that gives explanatory power to this discourse. The technical (effectiveness) theory posited that an organization is technically efficient, if it is adequate for the demand made on it. What the technical theorists are saying is that efficiency of the public administrators should be measured by how well they have performed in meeting the objectives of the organization. That is, to provide and deliver essential services and goods to the public at an affordable price and at the right time.

Target (operational) theory is concerned with a situation where a number of different units are operating in a number of different environments. Public sector comprises of the department, ministries and others like public corporations. It is through these organizations, which makes up the public sector that government carries it activities (Akpan, 1982:13). An organization might try to be efficient but it activities - its interdependency or inter-relationship with other departments - might affect negatively or positively its efficiency. From the aforementioned theories on how efficiency in the public sector can be measured, the best of them is target theory because, embedded in it are all other theories on public sector efficiency.

Another theory that is relevant to this discourse is the modernization theory. The modernisation school of thought was the first attempt to articulate the problem of development in terms of the need to transform the backward "traditional" nature of Third World economies into "modern" economies. Drawing from the historical experience of the Western Europe after World War II, under the Marshal Plan, it 
advocated the need for accelerated economic growth through an import substitution form of industrialisation, a process seen to entail securing the right quantity and mix of saving investment and foreign aid. Given the relatively low levels of new capital formation in most Third World countries, one obvious policy implication was the need for massive capital investment through foreign aid.

Modernization theorists were concerned with structural change in the economy and the process that had an economy from a state of primitive organization of production to the modem organization of economic activities (Huntington, 1968:12). Emphasis on the transformation of a traditional society into a modern one suggests that the outcry against corruption amount to a puritan reaction to modernization. In this view, corruption represents a deviation from ethical norms. Thus, looking at corruption from the modernization perspective reflect a strong anti-state position which Huntington cited by Abu (2007:45) summarised best by stating that in terms of economic growth, the only thing worse than a society with a rigid over centralized, dishonest bureaucracy is one with a rigid, over centralized bureaucracy. It is instructive to note that the modernization theory had been replaced with the principal-agent theory by the neoclassical economists. In their view, corruption amounts to principal-agent problem (Abu, 2007:58). In this case, it is the state which is the principal that entrusts the task of allocation rights to appropriate resources to its agents, i.e., the administrators. This means that there would be no corruption if the state had nothing useful for the private interests to allocate selectively.

Modernisation theories provoked a great deal of criticisms from radical scholars such as Andre Gunder Frank, Claude Ake, Bode Onimode, Shegu Oshoba, Zwingina Silas and others who argued that colonialism and Western capitalism were the two major factors responsible for the underdeveloped nature of Third World countries. The Western industrialised countries developed by exploiting human and natural resources of their colonies and by making them economically dependent on their colonial powers after independence. Neo-colonialism continues as western industrialised countries continue their political and economic domination of their former colonies. The theory states that development in metropolitan capitalism is the underdevelopment in the periphery.

The modernisation theory is adopted in this study because the behaviour of leaders in Africa shows that they lack the personality trait and motivation skill that will lead to growth and development.

\section{Corruption in Nigeria: Historical Perspective}

Corrupt practices are not issues just beginning today in our society; its history is as old as the world (Lipset \& Lenz, 2000:3). Most countries around the globe are noted for their area(s) of specialization. Nigeria is best known for her corrupt practices, and this has been on for decades. The country formally came into existence about a hundred years ago and more precisely in 1914 with the amalgamation of the Northern and Southern protectorates by Lord Lugard. According to Fawole (2013:9) there was no objective 
criterion for the amalgamation except for the administrative convenience of the British colonialist. The Northern and Southern protectorates had little or nothing in common.

From 1960 to date, the word 'corruption' has become the order of the day in every facet of our national life. No wonder that the Transparency International (TI), an organization based in Germany has consistently rated Nigeria as one of the most corrupt country over the last one decade. During the second term of Chief Olusegun Obansanjo as a civilian president, there were rays of hope, as he indicated his willingness to hold the bull by the horn and tackle the "hydra-headed" monster called corruption, considering several institutions established to combat corruption including the Independent Corrupt Practice and other Related Offences Commission (ICPC) and Economic and Financial Crimes Commission (EFCC) which came into being in 2000 and 2004 respectively under the administration of President Olusegun Obasanjo to deal with other unethical practices in the high and low places. This is an effort which has not been sustained by subsequent civilian administrations in the country. This is why today, some school of thought believe that the EFCC is more corrupt than when it started because after Mallam Ribadu left the organisation, the institution is yet to win a case levelled against some notorious corrupt officers. The EFCC has been rendered useless by the National Assembly and it is now a toothless bulldog.

\section{The Nature and Causes of Comuption in Nigeria}

It is extremely appalling that despite the long years of independence, Nigeria, the so called "giant" of Africa is still battling with the problem of good governance. The crop of leaders that have attained leadership position since independence had in one way or the other lacked vision, most of them have been engrossed with corruption and political bickering leading to the enthronement of maladministration and mismanagement of public resources, and consequently economic setback and abject poverty as nation heritage (Lawal \& Owolabi, 2012:9). Since Independence in 1960, corruption has persisted and grown enormously in variety and magnitude. Pervasive corruption endures in both the private and public sectors of the Nigeria society; however, the emphasis here is on public sector corruption which contributes more than $70 \%$ of the corruption cases in Nigeria and as well, seen as the source of heightened divide between Nigeria's wealth and its poverty (Abiodun, 2012:5). Significantly, Nigeria is among the countries of the world endowed with immense natural and human resources that are capable of improving socio-economic status and living standards of the citizenry; but the reverse has always been the case. In view of this ugly trend, one begins to wonder what kind of superficial "giant" position Nigeria claims to hold in Africa, after almost fifty three (53) years of independence with nothing to show for it.

Even though no country in the world is corrupt free, corruption in the case of Nigeria has become very worrisome because she has consistently been placed among the most corrupt nations in the world. The pervasive and deep rooted nature of corruption in Nigeria is indicated by the fact that in 1996, Transparency International (TI) ranked Nigeria as the 2nd most corrupt nation among the 54 nations surveyed. In 1998, Nigeria 
was again ranked the 2 nd most corrupt nation out of the 85 countries polled by TI. In 2001, Nigeria was ranked 90 out of 91 countries polled. By 2009, the Global Corruption Perception Index (CPI) by TI rated Nigeria 130th out of the 180 countries surveyed. For the year, 2010, Nigeria ranked 134th out of 178 countries assessed. In 2011, the TI, in its report on corruption perception, rated Nigeria as the 143 most corrupt nations out of the 183 countries surveyed (Chukwuemeka, et al, 2012; Lipset \& Lenz, 2000:244; Abiodun, 2012:7).

There are varieties of corruption as they manifest in Nigeria, these include: political, bureaucratic, private, public, materialistic and non-materialistic corruption, petty corruption and grand corruption, systemic and non-systemic corruption, etc (Fawole, 2013:5). According to him, grand corruption, otherwise known as "State Robbery" in the public sector is the main problem in Nigeria. 'State Robbery' is a variety of corruption where members of the political and bureaucratic elite simply plunder the national treasury through brazen theft, or through other ingenious methods ranging from deliberate alteration of documents, facts and figures to make money; outright collection of bribe, the type we heard so much about in the National Assembly, which led to the removal of a Senate President who allegedly demanded and obtained cash incentives from a Minister of Education; deliberate embezzlement of funds, such as is acted out in Ministries, Departments and Agencies (MDAs) to mop up unspent funds before the close of the financial year. Other varieties of 'State Robbery are falsification of contract figures through inflation, over-invoicing, periodic upward reviews of contract sums, a practice that still goes on in MDAs; contract splitting, an offence for which Chief Olabode George, a People Democratic Party Chieftain who was Chairman of the Nigeria Port Authority (NPA) went to jail; fraud, graft, misappropriation and misapplication of funds for personal aggrandisement; payoffs and contract kickbacks; and several others such as profiteering, shadiness, prolificacy, distortion, doctoring, falsification, etc.

Experiences in Nigeria seem to support the view that political and administrative malfeasance feed on each other (Abu, 2007:39). Over centralization of authority, and under or over-elaborated rules of authority is a major contributory factor to governmental corruption. The evil called corruption at the highest level distorts competition by denying the public access to competitive market place (Pope, 1996:26). Also, great inequality in the distribution of national wealth; the reliance on political office as the primary means of gaining access to wealth; the conflict between changing moral codes; the weakness of social and governmental enforcement mechanism; and the absence of strong sense of national community have been identified as other causes of corruption.

As a matter of fact, corruption in Nigeria has resulted to a reduction in the quality and quantity of goods and services available to the public as reflected in poor infrastructures, poor quality of education standards, poor health facilities and high cost of living and rising social insecurity. On the aspect of political development, corruption has often led to the inability of the nation to develop and consolidate its democratic practice as excessive corruption has often led to erosion of government legitimacy, defective 
leadership input and democratic destabilization through military takeover of government and truncation of civilian rule (Abiodun, 2012:21; Ugwuanyi, 2011:29).

There is no doubt that at the root of corruption quagmire in Nigeria is the failure and virtual collapse of governance, the contamination of democratic values, the erosion of accountability procedures, and the prevalence of bad leadership. Thus, the consequences of corruption can be disastrous. Corruption and carelessness are said to be at least partially responsible for the very heavy death toll in the massive earthquake that struck Haiti in 2010. There is no doubt that the scourge of corruption has impacted governance significantly in developing countries where it is mostly perpetrated.

Corruption undermines the legitimacy of government and democratic values of trust and tolerance. Corruption increases the cost of business through the price of illicit payments. It generates economic distortions in the public sector by diverting public investment into capital projects where bribes and kickbacks are more plentiful. Corruption also lowers compliance with construction, environmental, or other regulations, reduces the quality of government services and infrastructure, and increases budgetary pressures on government. Also, some other consequences of corruption include the fact that it can make other people suffer for the corrupt practices of an individual. An example was a situation where the education of a child is stopped because of corrupt practice of people in leadership position who have failed in their responsibility in addressing the education problem in the country (Adesuyi, 2013:13). The effect of corruption is grave that many organisations have been established to monitor corruption and promote efforts to reduce it in governance globally.

Familoni (2007:7) and Dike (2003:121) agreed that corruption causes a reduction in quality of goods and services available to the public, as some companies could cut corners to increase profit margins. Corruption affects investment, economic growth, and government expenditure choices; it also reduces private investment and fuels inflation. Empirical evidence from a number of researches, for example, Bello Imam (2004:18) shows that corruption contributes immensely to inhibition of economic performance and consequently affects investment and economic growth which is antithetical to national development (quoted in Muhammed, et al, 2008:79). Moreover, corruption can also upset ethnic balance and exacerbates problems of national integration in developing countries. Familoni (2007:11) observes that if a corrupt but popular ethnic leader is replaced in his or her position, it may 'upset ethnic arithmetic', the cohorts may revolt and this may engender the disintegration of the state. Moreover, the legitimacy of a particular government can be destroyed by corruption. It has been a stumbling block to the people enjoying the economic and social fruits of democracy (Muhammed, Ayinla \& Muhhammad, 2008:83). Furthermore, corruption is said to have contributed significantly to mass poverty in Nigeria. It has rendered several millions of Nigerians jobless and uneducated. There is no doubt that corruption has been attributed to mass poverty which has been breeding all forms of extremisms in the country, most especially the Niger-Delta crisis and the recent Boko Haram insurgency which has threatened the security, unity and co-existence of Nigeria as a nation-state. 
The most damaging effect of corruption is that if left unchecked, it grows, intensifies and spreads like cancer to vital centres of government with powerful influences on the public. Already, the negative multiplier effect of corruption in Nigeria has manifested in the mass spread of poverty and the nation's unenviable position in the list of poor and under developed countries of the world (Chukwuemeka, et al, 2012:341). Corruption causes a serious development challenge, in the political sphere; it undermines democracy and good governance by weakening political processes. Corruption in elections subverts accountability and representation in policy making, in the judiciary it suspends the rule of law and in the public service it leads to unequal distribution of services (Dininio \& Kpundeh, 1999:8). Corruption wastes skills because time is often a huge waste to set up anti-corruption agencies to fight corruption and also to monitor public sectors. Above all, corruption diverts scarce public resources into private pockets, it weakens good governance; it also threatens democracy and erodes the social and moral fabrics of a country (Dike, 2008:1).

Within the context of the Nigerian state, it is not as if successive governments have not realized the problem posed by corruption to the socio-economic and political development of the country. Without doubt, successive governments at one point or the other have made series of attempts at combating corruption through series of anticorruption campaigns (Lawal \& Tobi, 2006:6). What is in doubt, however, is what the impact of this anti-corruption campaign is?

\section{Corruption and Good Governance: The Nigeria Dilemma}

According to World Bank study of sub Sahara Africa (SSA), "The problem of Africa's Development is a crisis of governance; the study affirms that because of the countervailing power that has been lacking, state officials in many countries including Nigeria have served their own interests without fear of being called to account (Lawal \& Owolabi, 2012:8). Although corruption is a global scourge, Nigeria appears to suffer tremendously from this malaise. Every one appears to believe that the nation has a culture of corruption; Nigeria is a rich nation floating on oil wealth, but almost none of it flows to the people. The countless reforms and lack of integrity on the part of leaders have left Nigeria as corrupt as ever. Politicians are expunged and later re-admitted into their parties; then, what hope is therein for good governance when the leadership is deeply entrenched in corrupt practices.

Corruption is a complex multifaceted and persistent cancerous phenomenon which bedevils Nigeria. In Nigeria, as in many African states, it is a malaise that inflicts the society (Obuah, 2010:29). The effects of corruption on a nation's socio-political and economic development are myriad. The negative effect impacts on economic growth as it, among other things, reduces public spending on education (Mauro, 1997:9). Familoni (2007:2) posits that corruption has taught the Nigerian a dangerous and wrong lesson that it does not pay to be honest, hardworking and law abiding. Through corrupt means, many political office holders acquire wealth and property in and outside Nigeria; and 
many display their wealth (which is beyond their means), but the society does not blink. It also makes a nation to lose international aids (Familoni, 2007:3). Corruption affects investment, economic growth and government expenditure choices; it also reduces private investment and fuel inflation. At a time a scholar came up with the remark that:

The 1996 study of corruption by Transparency International and Goettingen University ranked Nigeria as the most corrupt nation among 54 nations listed in the study, ...in 1998 Transparency International Corrupt Perception Index (CPI) of 85 countries, Nigeria was 81 out of 85 countries polled. And in the 2001 Corruption Perception Index (CPI), the image of Nigeria slipped further down (ranked 90 out of 91 countries polled), as the second most corrupt nation, with Bangladesh coming first... ... (Familoni, 2005:9-10).

Corruption has mainly contributed to the backwardness and failure of good governance in Nigeria. The country has not been able to implement policies which promote good governance and facilitate the development and success of the democratic process due to the prevalent existence of corruption at both high and low levels. There is no doubt that this development threatens the moral integrity of the nation and hampers her social and economic development (Esq and Mustapha, 2008:76). The Transparency International's (TI) 2011 Corruption Perception Index also indicates that "the vast majority of the 182 countries and territories assessed score below five on a scale of 0 (highly corrupt) to 10 (very clean)". In the report, Nigeria took the $143^{\text {rd }}$ place to stand as the $39^{\text {th }}$ most corrupt country among the nations of the world. In 2012, the TI also ranked Nigeria as the $35^{\text {th }}$ most corrupt nation in the world. Thus, according to the report, Nigeria scored 27 percent and placed $139^{\text {th }}$ out of about 174 countries surveyed worldwide. Nigeria therefore shared the same position with such countries as Azerbajan, Kenya, Nepal and Pakistan which are also steeped in corruption.

If good governance is conceived to include the capacity of a government to manage resources efficiently in order to improve the well being of the citizens, then bureaucratic corruption can thus be regarded as one of the main obstacles to good governance and development in Nigeria. Corruption has assumed a normal pattern of life in Nigeria. Consequently, the situation has rendered the Nigerian state a non-delivery state. Corruption has denied the Nigerian people the beauty of good governance (Lawal \& Tobi, 2006:644). Thus, corruption is now largely responsible for the seeming collapse of everything we hold dear. Public offices are now seen as avenues for self-enrichment rather than service.

Today, Nigeria has gradually become a country where no service is rendered without money exchanging hands. The system according to Maduabum (2012:6) has brought out the bestial underpinnings of the human nature. There is a deliberate attempt by everyone to outdo the next person in corrupt practices. In his words:

If you proclaim holiness or righteousness as a public officer, you stand a chance of becoming endangered species. The more daring and innovative 
you are in this vice, i.e. corruption, the more you earn public recognition through chieftaincy titles, honorary doctorate degrees while many women queue up to join your harem (Maduabum, 2012:9).

It must be noted that the deliberate lethargy of the Nigerian government in the Halliburton scam where those Nigerians indicted alongside some foreign nationals including the top aides of the former President Obasanjo freely enjoy their loot, their foreign accomplices, individuals and corporate have not only been tried, they have been variously convicted and duly penalized by their home governments (Olokode, 2012:20).

In addition, there are cases of corruption associated with the power sector privatization of the current civilian administration in Nigeria. The recent sale of power generating and distribution companies to different companies tied to former military rulers and some serving political office holders in the country is an official confirmation of the extent of institutionalized corruption which has eaten deep into the entire fabric of national life in Nigeria. Equally important is the $\$ 12$ million oil wealth windfall which was mismanaged by Nigerian leaders. Rather than ask past leaders question about their stupendous wealth, the current civilian administration in the country not only celebrates them, but also defends them in law court. A typical example in the view of Olokode (2012:12) is the role played by the Attorney-General of the Federation in shielding former President Babangida in court, over the oil windfall allegedly squandered by his administration.

Some cases of corrupt practices in Nigeria

\begin{tabular}{|c|c|c|c|c|}
\hline $\mathbf{S} / \mathbf{N}$ & Name & Case Status & $\begin{array}{l}\text { Amount } \\
\text { Involved }\end{array}$ & Status Suspect(s) \\
\hline 1 & $\begin{array}{l}\text { Ayo Fayose (former Governor of } \\
\text { Ekiti State) }\end{array}$ & $\begin{array}{l}\text { Arraigned on } 51 \\
\text { counts }\end{array}$ & N1.2 billion & $\begin{array}{l}\text { Case pending, } \\
\text { granted bail }\end{array}$ \\
\hline 2 & $\begin{array}{l}\text { Adenike, Grange (former } \\
\text { Minister of Health) }\end{array}$ & $\begin{array}{l}\text { Arraigned on } 56 \\
\text { counts }\end{array}$ & N300 million & $\begin{array}{l}\text { Discharged and } \\
\text { acquitted }\end{array}$ \\
\hline 3 & $\begin{array}{l}\text { Joshua Dariye (former Governor } \\
\text { Plateau state) }\end{array}$ & $\begin{array}{l}\text { Arraigned on } 23 \\
\text { counts }\end{array}$ & N700 million & $\begin{array}{l}\text { Case pending, } \\
\text { Granted bail since } \\
2007\end{array}$ \\
\hline 4 & $\begin{array}{l}\text { Saminu Turaki (former Governor } \\
\text { Jigawa state) }\end{array}$ & $\begin{array}{l}\text { Arraigned on } 32 \\
\text { counts }\end{array}$ & N36 billion & $\begin{array}{l}\text { Case pending, } \\
\text { Granted bail since } \\
2007\end{array}$ \\
\hline 5 & $\begin{array}{l}\text { Oji Uzor Kalu (former Governor } \\
\text { Abia state) }\end{array}$ & $\begin{array}{l}\text { Arraigned on } 107 \\
\text { state counts }\end{array}$ & N5 billion & $\begin{array}{l}\text { Case pending, } \\
\text { Granted bail since } \\
2008\end{array}$ \\
\hline 6 & $\begin{array}{l}\text { James Ibori (former Governor } \\
\text { Delta state) }\end{array}$ & $\begin{array}{l}\text { Arraigned on } 170 \\
\text { counts }\end{array}$ & N9.2 billion & $\begin{array}{l}\text { Case pending, } \\
\text { Granted bail since } \\
2008\end{array}$ \\
\hline 7 & Iyabo Obasanjo (former Senator) & $\begin{array}{l}\text { Arraigned on } 56 \\
\text { state counts }\end{array}$ & N10 million & $\begin{array}{l}\text { Case pending, } \\
\text { Granted bail since } \\
2008\end{array}$ \\
\hline 8 & $\begin{array}{l}\text { Luckylgbinedion (former } \\
\text { Governor of Edo state) }\end{array}$ & $\begin{array}{l}\text { Arraigned on } 191 \\
\text { state counts }\end{array}$ & N4.3 billion & $\begin{array}{l}\text { Case determined, } \\
\text { ordered to pay } \$ 25 \\
\text { million as fine }\end{array}$ \\
\hline
\end{tabular}


58 Corruption and the Challenges of Good Governance in the Nigerian Public Sector

\begin{tabular}{|c|c|c|c|c|}
\hline 9 & $\begin{array}{l}\text { Gabriel Aduku (former Minister } \\
\text { of Health) }\end{array}$ & $\begin{array}{l}\text { Arraigned on } 56 \\
\text { state counts }\end{array}$ & N300 million & $\begin{array}{l}\text { Discharged and } \\
\text { acquitted }\end{array}$ \\
\hline 10 & $\begin{array}{l}\text { Jolly Nyame (former Governor of } \\
\text { Taraba state) }\end{array}$ & $\begin{array}{l}\text { Arraigned on } 41 \\
\text { state counts }\end{array}$ & N1.3 billion & $\begin{array}{l}\text { Case pending, } \\
\text { Granted bail since } \\
2008\end{array}$ \\
\hline 11 & $\begin{array}{l}\text { Chimaroke Nnamani (former } \\
\text { Governor of Enugu state) }\end{array}$ & $\begin{array}{l}\text { Arraigned on } 105 \\
\text { state counts }\end{array}$ & N5.3 billion & $\begin{array}{l}\text { Case pending, } \\
\text { Granted bail since } \\
2007\end{array}$ \\
\hline 12 & $\begin{array}{l}\text { Michael Botmang (former } \\
\text { Governor of Plateau state) }\end{array}$ & $\begin{array}{l}\text { Arraigned on } 31 \\
\text { state counts }\end{array}$ & N1.5 billion & $\begin{array}{l}\text { Case pending, } \\
\text { Granted bail since } \\
2008\end{array}$ \\
\hline 13 & $\begin{array}{l}\text { Roland lyayi (former MD of } \\
\text { FAAN) }\end{array}$ & $\begin{array}{l}\text { Arraigned on } 11 \\
\text { state counts }\end{array}$ & N5.6 billion & $\begin{array}{l}\text { Case pending, } \\
\text { Granted bail since } \\
2008\end{array}$ \\
\hline 14 & $\begin{array}{l}\text { Prof. Babalola Borishade (former } \\
\text { Minister of Aviation) }\end{array}$ & $\begin{array}{l}\text { Arraigned on } 11 \\
\text { state counts }\end{array}$ & N5.6 billion & $\begin{array}{l}\text { Case pending, } \\
\text { Granted bail since } \\
2008\end{array}$ \\
\hline 15 & $\begin{array}{l}\text { Boni Haruna (former Governor of } \\
\text { Adamawa state) }\end{array}$ & $\begin{array}{l}\text { Arraigned on } 28 \\
\text { state counts }\end{array}$ & N254 million & $\begin{array}{l}\text { Case pending, } \\
\text { Granted bail by court } \\
\text { since } 2008\end{array}$ \\
\hline 16 & $\begin{array}{l}\text { Femi Fanikayode (former } \\
\text { Governor of Adamawa state) }\end{array}$ & $\begin{array}{l}\text { Arraigned on } 47 \\
\text { state counts }\end{array}$ & N250 million & $\begin{array}{l}\text { Case pending, } \\
\text { Granted bail since } \\
2008\end{array}$ \\
\hline 17 & Bode George (PDP Chieftain) & $\begin{array}{l}\text { Arraigned on } 68 \\
\text { state counts }\end{array}$ & N100 billion & $\begin{array}{l}\text { Jailed in October } \\
2009\end{array}$ \\
\hline 18 & $\begin{array}{l}\text { Rasheed Ladoja (former } \\
\text { Governor of Oyo state) }\end{array}$ & $\begin{array}{l}\text { Arraigned on } 33 \\
\text { state counts }\end{array}$ & N6 billion & $\begin{array}{l}\text { Case pending, } \\
\text { Granted bail since } \\
2008\end{array}$ \\
\hline 19 & $\begin{array}{l}\text { Senator Nichola Ugbane; Hon. } \\
\text { Elumelu and others }\end{array}$ & $\begin{array}{l}\text { Arraigned on } 158 \\
\text { state counts }\end{array}$ & N5.2 billion & $\begin{array}{l}\text { Case pending, } \\
\text { Granted bail since } \\
2009\end{array}$ \\
\hline 20 & $\begin{array}{l}\text { Hamman Bello Hammed (Ex CG } \\
\text { Customs) }\end{array}$ & $\begin{array}{l}\text { Arraigned on } 46 \\
\text { state counts }\end{array}$ & N2.5 billion & $\begin{array}{l}\text { Case pending, } \\
\text { Granted bail since } \\
2009\end{array}$ \\
\hline 21 & $\begin{array}{l}\text { Adamu Abdullahi (former } \\
\text { Governor of Nasarawa state) }\end{array}$ & $\begin{array}{l}\text { Arraigned on } 149 \\
\text { count charge }\end{array}$ & N15 billion & $\begin{array}{l}\text { Case pending, } \\
\text { Suspect on court bail }\end{array}$ \\
\hline 22 & $\begin{array}{l}\text { Attahiru Bafarawa (former } \\
\text { Governor of Sokoto state) }\end{array}$ & $\begin{array}{l}\text { Arraigned on } 47 \\
\text { count charge }\end{array}$ & N15 billion & $\begin{array}{l}\text { Case pending, } \\
\text { Granted bail by court }\end{array}$ \\
\hline 23 & $\begin{array}{l}\text { Hassan Lawal (former Minister of } \\
\text { Works) }\end{array}$ & $\begin{array}{l}\text { Arraigned on } 37 \\
\text { count charge }\end{array}$ & N75 billion & $\begin{array}{l}\text { Case pending, } \\
\text { Granted bail by court }\end{array}$ \\
\hline 24 & $\begin{array}{l}\text { Kenny Martins (Police } \\
\text { Equipment Fund) }\end{array}$ & 28 count charge & N7,740 billion & $\begin{array}{l}\text { Case pending, } \\
\text { Granted bail since } \\
2008\end{array}$ \\
\hline 25 & $\begin{array}{l}\text { Esai Dangabar, Atiku Abubakar } \\
\text { Kigo, Ahmed Inuwa Wada, John } \\
\text { Yakubu Yusufu, Mrs. Veronica } \\
\text { Ulonma Onyegbula and Sani } \\
\text { Habila Zira }\end{array}$ & 16 count charge & N32.8 billion & $\begin{array}{l}\text { Case pending, } \\
\text { Granted bail by court }\end{array}$ \\
\hline
\end{tabular}

Source: Economic and Financial Crime Commission (EFCC) cited in Mohammed 2013:130-131 
The current administration of Jonathan can hardly be exonerated from the several scams in Nigeria in recent times. Since the assumption of office in May 2011, ordinary citizens have been embarrassed and bewildered by the degree of corruption in the oil industry, the pension commission, and the mint and printing company. The monies involved run into billions of naira. Also, the Farouk Lawan and Otedola scandal seems to have been forgotten and institutions like EFCC and ICPC bark more than they can bite. The government has not been able to meaningfully investigate these occurrences and bring the perpetrators to book. These have great consequences for the effectiveness of government policies and institutions. According to Adeyemo (2013:12), a recent investigation reveals that this unabated corruption has left an estimated 11,886 federal government projects abandoned across the country. No wonder that the Gallup poll and KPMG report ranked Nigeria the second most corrupt country in the world and the most corrupt in Africa. Another study by the Economist Intelligence Unit says Nigeria is the worst place for a baby to be born in 2013. All these point to the fact that corruption persists in the country because the root of corruption is left intact. For one thing, under the current civilian administration, the Nigerian state remains a veritable arena for encouraging corruption.

The problem of corruption in Nigeria has become dreadfully endemic and successive Nigerian governments have come to realize the problem posed by corrupt practices to the nation's economic and political development and have at different time devised various means to curb its menace. Without doubt, corruption has permeated the Nigerian society and in the words of Achebe (1988) "anyone who can say that corruption in Nigeria has not yet become alarming is either a fool, a crook or else does not live in this country."

It should be noted that Nigeria has very good laws and constitutional provisions to combat corruption but there has been a general lack of implementation of these laws and this is one of the reasons why the nation is lagging behind in its campaign against corruption. Moreover, the leaders and the public officials who are supposed to spearhead this campaign against corruption are themselves unwilling and reluctant to fully commit to the course because they themselves are the masterminds behind the corrupt practices. As such, much is still desired in the fight against corruption in Nigeria, and unless something is done to increase the level of commitment of all the actors in this campaign, the country would continue to experience the adverse effects of this societal ill.

\section{Corruption and Good Governance in Nigeria: what needs to be done?}

The issue of corruption remains a challenge in the development of any society. In order to successfully combat corruption, there is the need for a mechanism that will drastically transform the culture and legacy of corruption. Positive transformation of Nigeria can only occur through addressing the root causes of corruption and through effective 
implementation of the legal mechanisms already in place. It is important to note that in spite of the efforts by government at all levels, corruption remains a key concern, and sustainable efforts are required through multifaceted approaches to curb the menace of corruption in order to bring about good governance to the populace.

Corruption has been universally acknowledged as antithetical to any development that can be sustained. Nigeria's experience so far in effective governance validates this statement because it has become very clear that to combat and prevent corruption in Nigeria, a multi-faceted approach must be adopted. In order words, for corruption to be combated towards ensuring effective governance and sustainable development, it has to be anchored on a new paradigm that stresses the platform of rule of law, justice, equity, truth, honesty, virtue and integrity.

Institutions of governance once created take a life of their own. Therefore, deliberate attempts should be made to ensure that these institutions are built on sound ethical values and orientations, their operators should be made to go through and imbibe enduring moral training and virtues that can be passed on to future generations in order to guarantee rectitude, transparency and accountability in public service. These can redress the decadence in agencies and organs of government, especially watchdog institutions such as the judiciary, police and anti graft bodies.

The Nigerian masses need to regenerate and restore high ethical standards and patriotism. It is important to state that the responsibility for monitoring the fight against corruption in the service fell on the anti-corruption desk officers in the Ministries, Department and Agencies, who are expected to be resolute and firm in their action. Also, a situation where the national honours list parades a 'rogues' gallery contradicts a genuine commitment to wage war against corruption. There is need to create an environment that will give room to the emergence of a strong civil society for the promotion of transparency, accountability and responsiveness in governance. The constriction of all loopholes being explored to perpetrate fraud is strongly advocated. Preventive measures have to be scaled up with more proactive accounting and audit controls in government ministries, departments and parastatals.

The code of Conducts Bureau should utilize e-government in order to publish a list of all public officials who have declared their assets as well as those who have not. This would ensure transparency in the assets declaration process and provide valuable information to whistle blowers such as the media and civil society who in the past lacked access to such information. Whistle blowing and protection for the blowers should be strengthened to nip all the negative devices and tendencies in the bud. There is the need to ensure that the anti-corruption agencies in the country are properly funded and equipped to effectively fight corruption.

The public procurement process in Nigeria is greatly flawed and this is one of the areas in which the government needs to step up its efforts through the training of both state and non state actors who to date have virtually little or no knowledge in the monitoring process and as such cannot determine if the prescriptions of the Public Procurement Act are duly followed. The Nigerian Government must also ensure that information related to public contracting opportunities and the names of winning 
bidders are at all times available to the citizenry as this would reduce the conspiracy that has plagued the system.

The present administration should invest anti-corruption crusade with more momentum by making it an ongoing crusade. Also, the crusade must be holistic and all embracing. All tiers or arms of government and the private sector must be carried along. In addition, attempt should be made to introduce and strengthen where they are in existence, government watchdog agencies- anti corruption bureaus like InspectorGeneral, Auditors-General and Ombudsman (government official appointed to receive and investigate complaints made by officials, etc)- which will identify corruption practices and bring them to public attention. Thus, the authorities should look inwards to revive the EFCC by not appointing police officers as EFCC head. There are retired military officers, such as military intelligence officers from the rank of Brigadier-General as well as retired State Security Service (SSS) directors that are very intelligent who can be appointed as EFCC head. Thus, Fadahunsi (2013) is of the view that if we continue to make police officers to head the commission, it will be like asking a cat to oversee a pack of meat in a corner.

The media is very important in demanding accountability in government through their ability to investigate and expose corrupt acts; hence freedom of press is an important tool in fighting corruption. Independent and free press will also help to combat corruption by working against the notion of the public that corruption is inevitable and that important people are free from investigation. The media will be used to raise public awareness, expose corruption and will assist to build a coalition to combat corruption (Olowu, 1993:39). The role of the media is critical in promoting good governance and the fight against corruption.

The reforms of the Public/Civil Service should be implemented genuinely instead of the present window dressing policy issues; in this regard, the involvement of the civil society becomes imperative. The Nigeria's value systems that promote corruption go beyond the frontiers of legal normative propositions to the need for socio-cultural normative standards that will correct the existing value systems. Therefore, the civil society's involvement in the anti-corruption crusade must go beyond the formal engagement of government and its officers in effective governance issues into the arena of challenging the cultural practices and values that "communicate" or "facilitate" corrupt practices.

Governments need to involve civil society and citizens in consultations on national policies and at all levels in the planning and delivery of services. Participation must be informed, institutionalized and inclusive. This way we can prevent the corrupt use of funds and make sure that disadvantaged groups are not excluded from the delivery of vital services.

Governments must build checks and balances into climate policy and publish flows of money so we can monitor where they go. Independent oversight bodies are also needed, but they must have salaried staff with technical expertise and no conflicts of interest. 


\section{Conclusion}

Corruption is like a cankerworm that easily eats deep into the social and moral fabric of any society or nation. Incidentally, corrupt practices sometimes take place in such a subtle and insidious manner that they may be unnoticed for a long time after they must have taken deep roots. That is why individuals should constantly be on guard in the course of social, business or political transactions by noting and clarifying uncertain nuances and in particular, making "scepticism" their watch word.

That corruption is a serious menace to effective democratic governance and sustainable development is an understatement. Indeed, corruption is a major factor responsible for the nation's comatose state of underdevelopment despite the abundant wealth. It is the reason why policy makers with executive immunity divert scarce public resources to uneconomic high profile projects that are detrimental to the provision of simple basic and highly essential projects like investment in education, health and other infrastructures such as good roads, portable water and power supply. The resultant consequences include an impoverished economy with enormous negative impact on the poor. Indeed, because of corruption, the citizens have lost trust in the political system, its institutions and leadership hence the violent clashes and litigations that usually trail election results (Abdulahi, et al, 2012:248). There is no doubt that good governance in Nigeria has been stagnant due to bureaucratic, political and electoral corruption and this article has shown that these three types of corruption greatly affect good governance. The conclusion then is that corruption in Nigeria can only be tackled through a systemic approach.

In this discourse, we have examined critically the issue of corruption and the challenges it poses for the goals of good governance in Nigeria. For the avoidance of doubt, it has been established that corruption can ruin a nation. Corruption undermines democracy and good governance by flouting or even subverting formal processes, reduces accountability and distorts representation in policy making. More generally, corruption erodes the institutional capacity of government as procedures are disregarded, resources are siphoned off, and public offices are bought and sold.

\section{List of References}

- Abdullahi, Y.Z; Abdullahi, H and Yelwa, M. 2012. Corruption in Nigeria: Towards A New Paradigm for Effective Democratic Governance and Sustainable Development. Academic Research International. 3(1):239-253

- Abiodun, A. 2012. Combating Financial Crimes and Corruption in Nigeria: Prevention versus Enforcement Strategies. A paper Presented in National workshop on Performance, Transparency, Accountably and Development at the Local Government Level organized by the Office of the Secretary to the Government of the Federation at Abuja, February- March. 
- Abu, M. 2007. The Spatial imprints of Corruption in Nigeria. in Lai Olurode and Remi Anifowose. (eds.). The Rich but Poor: Corruption and Challenges of Good Governance in Nigeria. Lagos: Faculty of Social Sciences, University of Lagos.

- Achebe, C. (1988). The Trouble with Nigeria. Enugu: Fourth Dimension Publishers.

- Aderonmu, J.A. 2011. Civil Society and Anti-corruption Crusade in Nigeria's Fourth Republic. Journal of Sustainable Development in Africa. 13(1):75-86.

- Adesuyi, G. 2013. Corruption: The Biggest Industry: ICPC Chairman. Daily Sun Newspaper, February 13. P. 13

- Adeyemo, T. 2013. Let's talk Corruption after Christmas. Tell Magazine, Nos 51/52, December 24, p.12.

- Agbu, O. 2003. Corruption and Human Trafficking: The Nigerian Case. West Africa Review 20(03).

- Akpan, A.U. 1982. Pubic Administration in Nigeria. Lagos: Longman Publishing Company

- Bello-Imam, I.B. 2004. Corruption and National Development in Bello-Imam, I.B. and Obadan, M.I. (eds). Democratic Governance and Development in Nigeria's Fourth Republic 1999-2003. Ibadan: University Press PIc.

- Chukwuemeka, E; Ugwuanyi, B.J and Ewuim, N. 2012. Curbing Corruption in Nigeria: The Imperatives of Good Leadership. African Research Review: An International Multidisciplinary Journal. 6(3):338-358

- Dike, V. 2008. Corruption in Nigeria: A New Paradigm for Effective Control. African Economic Analysis. www.africaeconomicanalysis.org.

- Dike, V.E. 2003. Democracy and Political Life in Nigeria. Zaria: Ahmadu Bello University Press.

- Dike, V.E. 2005. Corruption in Nigeria: A New Paradigm for Effective Control. Online Publication, Tuesday, November 18.

- Dininio, P. and Kpundeh, S.J. 1999. A Handbook on Fighting Corruption: Center for Democracy and Governance. Techincal Publications Series Washington, D.C

- Doig, R.A. 1995. Good Government and Sustainable Anti-Corruption Strategies: A Role for Independent Anti-Corruption Agencies? Public Administration and Development 15(2): 151-65.

- Esq, I.I and Mustapha, M.A. 2008. Combating corruption in Nigeria: The role of the Legislature Examined. The University of Ilorin Law Journal. 3\&4: 57-79. 
- Etannibi, E.O.A. 2002. Tracking Corruption and Abuse of office in a Democratic Society. Equal Justice: A Quarterly Publication of Human Rights Monitor. 2(7), July.

- Familoni, K. 2007. The Political Economy of Corruption. in Lai Olurode and Remi Anifowose (eds.). The Rich but Poor: Corruption and Challenges of Good Governance in Nigeria. Lagos: Faculty of Social Sciences, University of Lagos.

- Fatile, J.O and Adejuwon, K.D 2012. Democracy and Development under the Shadow of Corruption in Africa: The Nigeria's Fourth Republic in Perspective. International Journal of Physical and Social Sciences. 2(4):152-176.

- Fawole, A. 2013. It's Corruption, Mr President. Nigerian Tribune Newspaper, Tuesday, 8 January p.56.

- Huntington, S. 1968. Political Order in Changing Societies. New Haven: Yale University Press.

- Ikotun, A. 2004. Ethics in the Nigerian Public Service: An Analytical Perspective. Lagos: Concepts and Print, Nugalitho Productions.

- Lawal, G and Tobi, A. 2006. Bureaucratic Corruption, Good Governance and Development: The Challenges and Prospects of Institution Building in Nigeria. Journal of Applied Sciences Research. 2(10): 642-649

- Lawal, T and Owolabi, B. 2012. Leadership Debacle: The Bane of Good Governance in Nigeria. Afro Asian Journal of Social Sciences. 3(3.3):1-12

- Lipset, S.M., and Lenz, G.S. 2000. Corruption, Culture, and Markets. in Lawrence E. Harrison, and Samuel P. Huntington. (eds). Culture Matters. New York: Basic Books

- Maduabum, C.P. 2012. Code of Conduct/ Ethical Behaviour in the Practice of Public Administration in Nigeria. Text of the Speech delivered at the Annual NAPAS week on Wednesday, $25^{\text {th }}$ July, 2012 at Lagos State University, Ojo.

- Mauro, P 1997. The Effects of Corruption on Growth, Investment and Government Expenditure: A Cross-Country Analysis. in Kimberly Ann Elliot. (ed). Corruption and Global Economy. Washington, D.C: Institute for international Economics.

- Muhammed, A.Y., Ayinla, S.A. \& M.N. Adeoye 2008. Corruption and Its Implications on National Development under the Fourth Republic in H. A. Saliu , Jimoh, I.S, Yusuf N. and Ojo, E.O. (eds). Perspectives on Nation Building and Development in Nigeria: Political and Legal Issues. A publication of Faculty of Business and Social Sciences, University of Ilorin.

- Muhammed, S. 2013. Corruption in Nigeria: A Challenge to Sustainable Development in the Fourth Republic. European Scientific Journal. 9(4): 118-137 
- Obuah, E. 2010. Combating Corruption in a "Failed" State: The Nigerian Economic and Financial Crimes Commission (EFCC). Journal of Sustainable Development in Africa. 12(1): 27-53

- Ogundiya, I.S. 2010. Corruption: The Bane of Democratic Stability in Nigeria. Current Research Journal of Social Sciences. 2(4): 233-241.

- Okeke, E. 2010. The challenges of Governance in Nigeria: Broad Perspectives and implications for the Engineering Practice. Paper presented at the "Engineering is Development" Conference Organized by the Association of Consulting Engineers of Nigeria (ACEN). Held at Sheraton Hotel, Abuja 8-10 November.

- Olokode, R. 2012. Nigeria's Corruption Ranking: A Critical Analysis Viewpoint. The Punch Newspapers. Wednesday, December 19, 2012, p.20.

- Olokor, F. 2013. Nigeria has lost $\$ 400$ bn to graft. Punch Newspaper, Friday, March 1,p.2.

- Olowu, D. 1993. Roots and the Remedies of Governmental Corruption in Africa. Corruption and Reform. 7(3): 227-236.

- Omoluabi, P. 2007. The Psychological Concomitants of Corruption in Nigeria. in Olurode, L and Anifowose, R. (eds). Rich but Poor: Corruption and Good Governance in Nigeria. Lagos; Faculty of Social Sciences, University of Lagos

- Onuoha, E.I. 2005. The Effective Administration of Criminal Justice for the Prevention of Corruption Activities by Public officials. The Nigerian Position, in Resource Materials Series No:56.

- Pope, J. 1996. National Integrity Programme. In P Lengseth and K. Gait (ed). Partnership for Governance: 23-26.

- Richardson, P. 2008. Good Governance: The Challenge of Leadership in Africa. A paper presented at 2008 International Management Conference organised by Nigerian Institute of Management and Association of Management organisations in Africa at Manchester Business School, United Kingdom.

- Ugwuanyi, B.I. 2011. Electoral Violence in Nigeria: Causes and Implications for Proper and Sustainable Democratic Practice. Nigeria Journal of Administrative Science. 9.

\section{AUTHOR'S CONTACT}

FATILE, Jacob Olufemi

Department of Industrial Relations and Public Administration

Lagos State University, Ojo

Lagos, Nigeria

Email: jacofem@yahoo.com 